
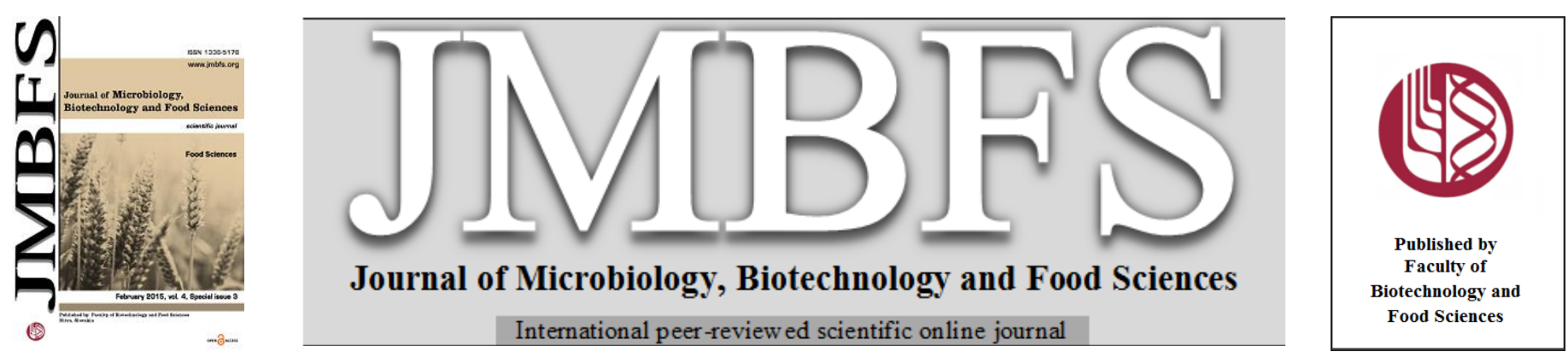

\title{
CHANGES IN AMARANTH POLYPHENOL CONTENT DURING THE DIFFERENT VEGETATION PHASES
}

\section{Alena Vollmannová ${ }^{* 1}$, Eva Margitanová ${ }^{1}$, Judita Bystrick $\dot{a}^{1}$, Tatiana Bojňanská ${ }^{2}$,Dana Urminská $\dot{a}^{3}$,Iveta Čičová ${ }^{4}$, Michaela Benková}

Address(es): prof. RNDr. Alena Vollmannová, PhD.

${ }^{1}$ Slovak University of Agriculture in Nitra, Faculty of Biotechnology and Food Sciences, Department of Chemistry, Tr. A. Hlinku 2, 94976 Nitra, Slovak Republic, phone number: +421376414374 .

${ }^{2}$ Slovak University of Agriculture in Nitra, Faculty of Biotechnology and Food Sciences, Department of Plant Products St orage and Processing, Tr. A. Hlinku 2, 94976 Nitra, Slovak Republic.

${ }^{3}$ Slovak University of Agriculture in Nitra, Faculty of Biotechnology and Food Sciences, Department of Biochemistry and Biotechnology, Tr. A. Hlinku 2, 94976 Nitra, Slovak Republic.

${ }^{4}$ National Agriculture and Food Centre, Plant Production Research Centre in Piestany, Slovak Republic.

*Corresponding author: alena.vollmannova@uniag.sk

doi: 10.15414/jmbfs.2015.4.special3.177-180

\section{ART ICLE INFO}

Received 27. 11.2014

Revised 3. 12. 2014

Accepted 4. 12. 2014

Published 2. 2. 2015

Regular article

open $\odot$ access

\section{ABSTRACT}

Total content of polyphenols was investigated in different anatomical parts of amaranth during different growth periods. Fiv e amaranth cultivars were included in the experiment (Amaranthus hypochondriacus L.: cultivars Annapurna and Koniz, Amaranthus caudatus L.: cultivar Oscar Blanco, Amaranthus cruentus L.: cultivars Golden Giant and Rawa). Analy sis were done in 4 growth phases: phase I. intensive stem growth, phase II. - formation of the flowers and pollination, phase III. - milky ripeness, phase IV. - full ripeness. Based on the determined total polyphenol content in amaranth it is possible to create this anatomical part order: leaves $>$ flowers $>$ seeds $>$ stems. No statistically significant differences were confirmed between phases I., III. and IV. On the other hand the total polyphenol content in amaranth determined in growth phase II. was significantly different in comparison to other growth phases. Statist ically significant differences in polyphenolic content were confirmed between all investigated anatomical parts of amaranth.

Keywords: Amaranth, polyphenolics, anatomical parts, growth phase

\section{INTRODUCTION}

Amaranths are plants of the genus Amaranthus. The cultivated forms are useful for producing nutritious grain and foliage, and as colorful ornamentals (Brenner et al., 2000). Amaranthus hypochondriacus, Amaranthus cruentus and Amaranthus caudatus are among the most widespread species of the family Amaranthaceae. In spite of the fact that the genus Amaranthus has been the subject of many taxonomic studies, it is still poorly understood and is widely considered to be a "difficult" genus. It constists of about 70 species, of which about 40 are native to the Americas and the rest to Australia, Africa, Asia and Europe (Costae, Demason, 2001).

Amaranth is a very versatile crop that is grown in a wide range of agro-climatic conditions; it resists drought, heat, and pests, and adapts readily to new environments (Rana et al., 2007).

Cultivated amaranth species can be used, not only as a source of edible seeds, leafy vegetables, and forage, but also as ornamentals (Mlakar et al., 2009) Amaranth contains between 15 and $22 \%$ protein, with a significantly higher content of lysine, and acceptable levels of tryptophan and methionine, and it contains 58 and 66\% st arch as well as 9 to $16 \%$ dietary fiber (Tosi et al., 2001). Lipid contents range between 7 and $8.5 \%$ with is higher than most other cereals Amaranth oil contains approximately $77 \%$ unsaturated fatty acids and is high in linoleic acid, which is necessary for human nutrition. The lipid fraction is unique due to the high squalene content (Sun et al., 2005). High concentrations of calcium, phosphorus, iron, potassium, zinc, vitamin E and B complex, as well as low levels of antinutritional factors, make this grain a product of high interest for food formulation. The very low glyadine content, less than $0.01 \%$ in some varieties (Amaranthus cruentus, A. mantegazzianus), makes useful for those who suffer from celiac disease (Tosi et al., 2001). Amaranth is a rich source of polyphenols (flavonoids) with relative high antioxidant activity. Caffeic acid, phydroxybenzoic acid and ferulic acid are the main phenolic compounds in amaranth grains (Klimczak et al., 2002). Barba de la Rosa et al. (2009) also detected low levels of quercetin glycoside, rutin $(4.0-10.1 \mu \mathrm{g} / \mathrm{g} \mathrm{DM})$ in amaranth seeds. Vegetable amaranth has received significantly less research attention than grain amaranth (Alegbejo, 2014). However, it has been rated considerably higher in minerals, such as calcium, iron, phosphorous (Makus, 1984; Igbok we et al.,
1988 ) and carotenoids (Martirosyan, 2001) than most vegetables. Amaranth leaves, stems and entire plants may be eaten raw or cooked. Cooking and discarding the water removes potentially harmful oxalates and nitrates (Babalola et al., 2010). Amaranth leaves have similar nutritional quality to spinach and other green materials. Except for the Fe content, pasta made from amaranth green leaves or spinach green leaves flour did not differ significantly in the amount of moisture, fat, protein, crude fiber, and total carbohydrate present (Borneo, Aguirre, 2008).

The aim of this study was to investigate the dynamics of total polyphenolics creation in different anatomical parts of five amaranth cultivars during different growth periods

\section{MATERIAL AND METHODS}

\section{Plant material}

Five cultivars from amaranth (Golden Giant, Rawa, Annapurna, Oscar Blanco, Koniz) were obtained from Plant Production Research Center in Piešt'any. Al cultivars are registered in the EU. The anatomical parts of amaranth were manually separeted, dried at $105^{\circ} \mathrm{C}$ to constant weight (WTC Binder, Germany) and powdered (Fritsch Pulverisette, Germany).

\section{Extract preparation}

Plant extracts were prepared by adding $25 \mathrm{~mL}$ of $80 \%$ methanol (Sigma-Aldrich USA) to $1 \mathrm{~g}$ milled sample. The mixture was shaken at room temperature for $8 \mathrm{~h}$ at $250 \mathrm{rpm}$. Samples were then filtered through filter paper $\left(130 \mathrm{~g} / \mathrm{m}^{2}\right.$, Filtrak, Germany) and kept at $8{ }^{\circ} \mathrm{C}$ for further analysis.

\section{Determination of total polyphenol content (TP)}

The total polyphenol content (TP) was estimated using Folin-Ciocalteau reagent (Merck, Germany) according Lachman et al. (2003). Sample extract (0.05 to 1 $\mathrm{mL}$ to the expected polyphenol content), $2.5 \mathrm{~mL}$ Folin-Ciocalteau reagent and 3 - 
$5 \mathrm{~mL} \mathrm{H}_{2} \mathrm{O}$ were added to a $50 \mathrm{~mL}$ flask. After $3 \mathrm{~min} .7 .5 \mathrm{~mL}$ of $20 \% \mathrm{Na}_{2} \mathrm{CO}_{3}$ (Sigma-Aldrich, USA) were added to the flask and diluted to $50 \mathrm{~mL}$ with $\mathrm{H}_{2} \mathrm{O}$. The mixture was incubated for $2 \mathrm{~h}$ at laboratory temperature and the absorbance was measured at $765 \mathrm{~nm}$ on the spectrophotometer Shimadzu 710 (Shimadzu, Japan) against the blank sample. The total polyphenol content was expressed as gallic acid equivalents (GAE) in $\mathrm{mg} / \mathrm{kg} \mathrm{DM}$ (dry matter). The linearity range for this assay was determined at $200-1000 \mathrm{mg} / \mathrm{mL}\left(\mathrm{R}^{2}=0,998\right)$.

\section{Statistical analysis}

All determinations were done in six repetitions. The dat a were analysed using the package Stat graphics (multifactorial analysis of variance, LSD-text contrast s, $p<$ $0.05)$.

\section{RESULTS AND DISCUSSION}

Total content of polyphenols was investigated in different anatomical parts of amaranth during different growth periods (stems. leaves, flowers and seeds). Five amaranth cultivars were included in the experiment (Amaranthus hypochondriacus L.: cultivars Annapurna and Koniz, Amaranthus caudatus L.: cultivar Oscar Blanco, Amaranthus cruentus L.: cultivars Golden Giant and Rawa). Analysis were done in 4 growth phases: phase I. - intensive stem growth, phase II. - formation of the flowers and pollination, phase III. - milky ripeness phase IV. - full ripeness (T able 1).

Table 1 Total content of polyphenols in different anatomical parts of amaranth cultivars in different growth phases (mg GAE/kg DM)

\begin{tabular}{|c|c|c|c|c|c|}
\hline \multirow{2}{*}{ Cultivar } & \multirow{2}{*}{ Plant material } & Phase I. & Phase II. & Phase III. & Phase IV. \\
\hline & & mg GAE/kg DM & mg GAE/kg DM & mg GAE/kg DM & mg GAE/kg DM \\
\hline \multirow{4}{*}{ Golden Giant } & steams & 969.03 & 1450.10 & 1449.75 & 1723.73 \\
\hline & leaves & 4333.79 & 4042.35 & 3093.69 & 4610.92 \\
\hline & flowers & 0.00 & 2532.19 & 3261.44 & 0.00 \\
\hline & seeds & 0.00 & 0.00 & 0.00 & $2548.75 \mathrm{~b}$ \\
\hline \multirow{4}{*}{ Rawa } & steams & 1464.75 & 1716.46 & 1373.42 & 1935.41 \\
\hline & leaves & 3605.35 & 8854.52 & 3302.83 & 3763.96 \\
\hline & flowers & 0.00 & 4707.67 & 4835.50 & 0.00 \\
\hline & seeds & 0.00 & 0.00 & 0.00 & $1381.05 \mathrm{a}$ \\
\hline \multirow{4}{*}{ Annapurna } & steams & 1539.96 & 1413.23 & 1390.78 & 1530.33 \\
\hline & leaves & 3619.15 & 4117.35 & 4158.58 & 3338.27 \\
\hline & flowers & 0.00 & 3374.63 & 3578.54 & 0.00 \\
\hline & seeds & 0.00 & 0.00 & 0.00 & $2869.90 \mathrm{~b}$ \\
\hline \multirow{4}{*}{ Oscar Blanco } & steams & 1115.30 & 1343.07 & 1623.38 & 1161.52 \\
\hline & leaves & 5775.25 & 8457.29 & 4998.13 & 4202.33 \\
\hline & flowers & 0.00 & 3856.40 & 3938.31 & 0.00 \\
\hline & seeds & 0.00 & 0.00 & 0.00 & $1634.10 \mathrm{a}$ \\
\hline \multirow{4}{*}{ Koniz } & steams & 1122.90 & 1092.29 & 1274.02 & 1924.42 \\
\hline & leaves & 3605.77 & 6740.68 & 4613.15 & 4481.79 \\
\hline & flowers & 0.00 & 4096.08 & 4029.67 & 0.00 \\
\hline & seeds & 0.00 & 0.00 & 0.00 & $1807.81 \mathrm{a}$ \\
\hline
\end{tabular}

The different letter in column denotes a statistically significant difference $(\mathrm{P}<0.05)$; TP - total polyphenol content; SD - standard deviation, $\mathrm{DM}$ - dry mater.

The dat a relating to total polyphenol content in seeds of amaranth in the literature are very diverse. While determined values of TP in amarath seeds by Mošovská et al. (2010), Gorinstein et al. (2007), Klimczak et al. (2002) and Czerwinski et al. (2004) were 1048.8, 430, 391 - 562 and even 149 mg GAE.kg-1 DM respectively, Dlamini et al. (2010) reported significantly higher amount of TP in amaranth seeds $(17600 \mathrm{mg} \mathrm{GAE} / \mathrm{kg})$. Our results are in correlation to those presented by Paśko et al. (2008) who analysed seeds of 2 amaranth cultivars and determined the similar values of total polyphenol content (2950 and $3000 \mathrm{mg}$ GAE/kg DM respectively) and Guzmán-Maldonado., Paredes-Lûpez (1998), who presented total polyphenol content in amaranth seeds in interval $2000-4000$ mg GAE/kg DM.
Total polyphenol content (TP) in stems and leaves was determined in all four growth phases (Table 1). The obtained results confirmed in all growth phases a higher polyphenol content in leaves of all cultivars compared with stems. The determined values of total polyphenols ( $\mathrm{mg} \mathrm{GAE} / \mathrm{kg}$ ) in stems of observed amaranth cultivars in I., II., III. and IV. growth phases were intervals 969.03 $1539.96,1092.29-1716.4,1274.02-1623.38$ and 1161.52 , while in leaves were the determined values of TP $(\mathrm{mg} \mathrm{GAE} / \mathrm{kg})$ in growth phases I., II., III. and IV. in intervals $3605.35-5775.25,4042.35-8854.52,3093.69-4998.13$ and 3338.27 -4610.92 respectively.

Table 2 Total Average values of total polyphenol content in stems and leaves of amaranth in different growth phases (mg GAE/kg DM)

\begin{tabular}{|c|c|c|c|}
\hline \multirow{2}{*}{ Anatomical Part } & \multirow{2}{*}{ Growth phase } & TP & \multirow{2}{*}{ SD } \\
\hline & & mg GAE/kg DM & \\
\hline \multirow{4}{*}{ Stems } & I. & $1242.22 \mathrm{a}$ & 246.48 \\
\hline & II. & $1403.03 \mathrm{ab}$ & 224.00 \\
\hline & III. & $1422.27 \mathrm{ab}$ & 128.99 \\
\hline & IV. & $1655.08 \mathrm{~b}$ & 322.10 \\
\hline \multirow{4}{*}{ Leaves } & I. & $4187.86 \mathrm{c}$ & 941.10 \\
\hline & II. & $6442.44 \mathrm{~d}$ & 2298.54 \\
\hline & III. & $4033.28 \mathrm{c}$ & 821.47 \\
\hline & IV. & $4079.45 \mathrm{c}$ & 526.38 \\
\hline
\end{tabular}

The different letter in column denotes a statistically significant difference $(\mathrm{P}<0.05)$; $\mathrm{TP}$ - total polyphenol content; SD - standard deviation, DM - dry mater.

Statistically significant differences in total polyphenol content was determined in amaranth stems only between growth phases I. and IV. and in leaves between growth phase II. and the other investigated growth phases of amaranth plant
(Table 2). In leaves the determined TP content was almost 3.3 times higher compared with stems. 
Table 3 Average values of total polyphenol content in stems, leaves and flowers of amaranth in growth phases II. and III. (mg GAE/kg DM)

\begin{tabular}{cccc}
\hline \multirow{2}{*}{ Anatomical Part } & \multirow{2}{*}{ Growth phase } & TP & \multirow{2}{*}{ SD } \\
\cline { 2 - 4 } Stems & II. & $1403.03 \mathrm{a}$ & 224.00 \\
\cline { 2 - 4 } & III. & $1422.27 \mathrm{a}$ & 128.99 \\
\hline \multirow{2}{*}{ Leaves } & II. & $6442.44 \mathrm{c}$ & 2298.54 \\
\cline { 2 - 4 } & III. & $4033.28 \mathrm{c}$ & 821.47 \\
\hline \multirow{2}{*}{ Flowers } & II. & $3739.39 \mathrm{~b}$ & 516.32 \\
\cline { 2 - 4 } & III. & $3928.69 \mathrm{~b}$ & 591.70 \\
\hline
\end{tabular}

The different letter in column denotes a st atistically significant difference $(\mathrm{P}<0.05) ; \mathrm{TP}-$ total polyphenol content; SD - standard deviation, DM - dry mater.

In growth phases II. and III. the total polyphenol content in stems, leaves and flowers was determined (Table 1). The highest polyphenol content in amaranth flowers in phases II. and III. was detected in cv. Rawa (4707.67 and $4835.50 \mathrm{mg}$ GAE/kg respectively). The highest value of TP in stems and leaves in growth phase II. was determined in cv. Rawa (1716.46 and $8854.52 \mathrm{mg} \mathrm{GAE} / \mathrm{kg}$ respectively) while in growth phase III. (milky ripeness) in cv. Oscar Blanco (1623.38 and $4998.13 \mathrm{mg} \mathrm{GAE} / \mathrm{kg}$ respectively).
Based on the results the followed order of total polyphenol content in investigated amaranth anatomical parts can be created: leaves $>$ flowers $>$ stems. Statistically significant differences in polyphenolic content were confirmed between all investigated anatomical parts of amaranth (Table 3).

Table 4 Average values of total polyphenol content in stems, leaves and seeds of amaranth in growth phase IV. (mg GAE/kg DM)

\begin{tabular}{|c|c|c|c|}
\hline \multirow{2}{*}{ Anatomical Part } & \multirow{2}{*}{ Growth phase } & $\mathbf{T P}$ & \multirow{2}{*}{ SD } \\
\hline & & mg GAE/kg DM & \\
\hline Stems & IV. & $1655.08 \mathrm{a}$ & 322.10 \\
\hline Leaves & IV. & $4079.45 \mathrm{~b}$ & 526.38 \\
\hline Seeds & IV. & $2048.32 \mathrm{a}$ & 632.47 \\
\hline
\end{tabular}

The different letter in column denotes a statistically significant difference $(\mathrm{P}<0.05)$; TP - total polyphenol content; SD - st andard deviation, DM - dry mater.

In growth phase IV. the total polyphenol content was determined in three anat omical parts of amaranth plants (stems, leaves, seeds). In leaves 2.76 times higher values compared with stems and 1.9 times higher values of TP content compared with seeds were determined (Table 1). The highest TP content in seeds was determined in cv. Annapurna, the lowest one in cv. Rawa. The determined values of TP content in leaves were statistically significantly different from the other investigated anatomical parts of amaranth plant (Table 4).

Based on the determined total polyphenol content in amaranth it is possible to create this anatomical part order: leaves $>$ flowers $>$ seeds $>$ stems.

No statistically significant differences were confirmed bet ween phases I., III. and IV. On the other hand the total polyphenol content in amaranth determined in growth phase II. was significantly different in comparison to other growth phases. Statistically significant differences in polyphenolic content were confirmed between all investigated anatomical parts of amaranth.

\section{CONCLUSION}

Amaranth as a pseudocereal is an excellent source of highly appreciated nutritional components as well as other bioactive compounds such as polyphenolics, beta-carotene and lutein. Grain amaranth species that have high level of proteins should be promoted in developing countries as a source of proteins. On the other hand also amaranth leaves, stems and entire plants may be eaten raw or cooked. Amaranth leaves have similar nutritional quality (moist ure, fat, protein, crude fiber, and total carbohydrate content) to spinach and other green vegetables. Leaves of amaranth contain also high amount of polyphenols with benefit on the human health due to their antioxidant activity. Based on the determined total polyphenol content in investigated amaranth cultivars it is possible to create this anatomical part order: leaves $>$ flowers $>$ seeds $>$ stems.

Acknowedgments: This work was co-funded by European Community under project No. 26220220180: Building Research Centre "AgroBioT ech" and also supported by project: VEGA $1 / 0308 / 14$

\section{REFERENCES}

ALEGBEJO, J.O. 2014. Nutritional value and utilization of amaranthus (Amaranthus spp.) - a review. Bayero Journal of Pure and Applied Sciences, 6(1), 136-143. http://dx.doi.org/10.4314/bajopas.v6i1.27

BABALOLA, O.O., TUGBOBO, O.S., DARAMOLA, A.S. 2010. Effect of Processing on the Vitamin C Content of Seven Nigerian Green Leafy Vegetables. Advance Journal of Food Science and Technology, 2(6), 303-305. ISSN: 2042 4876. http://maxwellsci.com/print/ajfst/v2-303-305.pdf

BARBA de la ROSA A.P. et al. 2009. Amaranth (Amaranthus hypochondriacus) as an alternative crop for sustainable food production: Phenolic acids and flavonoids with potential impact on its nutraceutical quality. Journal of Cereal Science, 49, 117-121. http://dx.doi.org/10.1016/j.jcs.2008.07.012
BORNEO, R., AGUIRRE, A. 2008. Chemical composition, cooking quality, and consumer acceptance of pasta made with dried amaranth leaves flour. $L W T-$ Food Science and Technology, 41(10), 1748-1751. http://dx.doi.org/10.1016/j.lwt.2008.02.011

BRENNER, D.M. et al. 2000. Genetic resources and breeding of Amaranths. Janick Jules (Ed.). Plant breeding reviews, 18, 227-285. COSTEA, M. DEMASON, D. 2001. Stem morphology and anatomy in Amaranthus L. (Amaranthaceae). Journal of the Torrey Botanic Society, 128(3), 254-282. http://dx.doi.org/10.1002/9780470650172.ch7

CZERWIŃSKI, J. et al. 2004. Oat (Avena sativa L.) and amaranth (Amaranthus hypochondriacus) meals positively affect plasma lipid profile in rats fed cholesterolcontaining diets. Journal of Nutritional Biochemistry, 15(10), 622 629. http://dx.doi.org/10.1016/j.jnutbio.2004.06.002

DLAMINI, N. R. et al. 2010. Indigenous edible plants as sources of nutrients and health benefitting components (nutraceuticals). CSIF $3 \mathrm{rd}$ Biennial Conference 2010 Science Real and Relevant. CSIR Internatioal Convention Center, Pretoria http://researchspace.csir.co.za/dspace/handle/10204/4224

GORINSTEIN, S., VARGAS, O.J.M., JARAMILLO, N.O., SALAS, I.A. AYALA, A.L.M., ARANCIBIA-AVILA, P. TOLEDO, F., KATRICH, E. TRAKHTENBERG, S. 2007. The totalpolyphenols and antioxidant potentials of some selected cereals and pseudocereals. European Food Research and Technology, 225(3-4), 321-328. http://dx.doi.org/10.1007/s00217-006-0417-7 GUZMÁN-MALDONADO S.H., PAREDES-LÛPEZ O. 1998. Functional products of plants indigenous to Latin America: amaranth, quinoa, common beans and botanicals. In: Mazza G. (ed.), Functional Foods: Biochemical and Processing Aspects. Lancaster: Technomic Publishing Co. Inc., 293-328.

IGBOKWE, P.E. et al. 1988. Amaranth - A potential crop for southwestern Mississippi. Res. Rep. Mississippi Agr. Forestry Expt. Sta. 13(10), 4.

KLIMCZAK, I., MAŁECKA, M., PACHOŁEK, B. 2002. Antioxidant activity of ethanolic extracts of amaranth seeds. Molecular Nutrition \& Food Research, 46 184-186. http://dx.doi.org/10.1002/1521-3803(20020501)46:3<184::aidfood $184>3.0 . \operatorname{co} ; 2-\mathrm{h}$

LACHMAN, J., HEJTMÁNKOVÁ, A., DUDJAK, E et al. (2003). Content polyphenolic antioxidants and phenolcarboxylic acids in selected parts of yacon. Vitamins 2003 - Prírodní antioxidanty a volné radikály. Pardubice : Univerzita Pardubice, 89-97.

MAKUS, J.D. 1984. Evaluation of amaranth as a potential green crop in the midsouth. Hort. Science, 19, 881-883.

MART IROSYAN, D.M. 2001. Amaranth as a Nutritional Supplement for the Modern Diet. Amaranth Legacy, USA. 14, 2-4.

MLAKAR, S.G., TURINEK, M. JAKOP, M. BAVEC, M., BAVEC, F. 2009. Nutrition value and use of grain amaranth: Potential fut ure application in bread making. Agricultura, 6(10), http://www.agriculturaonline.com/portal/issues/issue-10/109-nutrition-value-and-use-of-grainamaranth-potential-future-application-in-bread-making 
MOŠOVSKÁ, S., MIKULÁŠOVÁ, M., BRINDZOVÁ, L., VALÍK, L., MIKUŠOVÁ, L. 2010. Genotoxic and antimutagenic activities of extracts from pseudocereals in the Salmonella mutagenicity assay. Food and Chemical Toxicology, 48(6), 1483-1487. http://dx.doi.org/10.1016/j.fct.2010.03.015 PASKO, P., SAJEWICZ, M., GORINSTEIN, S., ZACHWIEJA, Z. 2008. Analysis of the selected phenolic acids and flavonoids in Amaranthus cruentus and Chenopodium quinoa seeds and sprouts by HPLC method. Acta Chromatographica, 20(4),

661-672.

http://dx.doi.org/10.1556/achrom.20.2008.4.11

RANA, J.C. et al. 2007. Durga: A new variety of grain amaranth for cultivation in hill regions. Indian Farming, 57(1), 27-28.

SUN, T., HO, C.T. 2005. Antioxidant activity of buckwheat extracts. Food Chem istry, 90(4), 743-749. http://dx.doi.org/10.1016/j.foodchem.2004.04.035

TOSI, E.A., LUCERO, E.R.H., MASCIARELLI, R. 2001. Dietary fiber obtained from amaranth (Amaranthus cruentus) grain by differential milling. Food Chem istry, 73(4), 441-443. http://dx.doi.org/10.1016/s0308-8146(00)00326-5 